\author{
STUDIA POLONIJNE \\ T. 42 LUBLIN 2021 \\ DOI: $\frac{\text { http://doi.org/10.18290/sp2 } 142.2}{4}$
}

JERZY GRZYBOWSKI

\title{
ŻYCIE CODZIENNE POLSKICH ROBOTNIKÓW ROLNYCH NA ŁOTWIE W LATACH 1928-1939*
}

Na początku XX wieku pojawił się nowy model odtwarzania dziejów, który polegał na uwzględnieniu w badaniach analizy wszystkich dziedzin życia człowieka, nie tylko jednostek wybitnych, lecz również wszystkich ludzi niegdyś żyjących. Wojciech Skóra trafnie zauważa, że jednym z elementów tego podejścia do przeszłości stało się zainteresowanie życiem codziennym ludzi i społeczności niebiorących udziału w wielkich wydarzeniach historycznych. Historycy zaczęli korzystać z dokonań wszystkich innych nauk o człowieku w celu odtworzenia nie tylko dziejów struktur politycznych czy wybitnych jednostek, lecz ludzi i zjawisk dotychczas pomijanych w badaniach ${ }^{1}$.

Powyższy model odtwarzania przeszłości okazuje się bardzo przydatny w badaniach nad emigracją zarobkową, której uczestnikami są nie wybitne osobowości, lecz zwykli ludzie. Celem tej publikacji jest próba ukazania życia codziennego polskich robotników sezonowych na Łotwie w okresie międzywojennym.

Emigracja zarobkowa z Polski do Łotwy w okresie międzywojennym była konsekwencją sytuacji społeczno-gospodarczej w obu tych państwach. Bezpośrednim powodem tej emigracji był niedostatek materialny w kraju idący $\mathrm{w}$ parze $\mathrm{z}$ dostępem do zagranicznego rynku pracy. Przeludnienie agrarne i problem „ludzi zbędnych” w Polsce zbiegł się w czasie z deficytem siły roboczej $\mathrm{w}$ rolnictwie łotewskim. Radykalnie przeprowadzona $\mathrm{w}$ pierwszych

Dr hab. JERZY GRZYBOwSKI, prof. UW - Katedra Studiów Interkulturowych Europy Środkowo-Wschodniej, Wydział Lingwistyki Stosowanej Uniwersytetu Warszawskiego; e-mail: jgrzybowski @uw.edu.pl; ORCID: https://orcid.org/0000-0002-7359-487X.

${ }^{*}$ Publikacja jest wynikiem realizacji projektu badawczego (nr rejestracyjny 2018/31/B/HS3/ 02042) realizowanego z grantu Narodowego Centrum Nauki.

${ }^{1} \mathrm{~W}$. SKÓRA, Życie codzienne polskich robotników rolnych na Pomorzu Zachodnim $w$ dwudziestoleciu międzywojennym, [w:] Życie dawnych Pomorzan, cz. 1, red. W. Łysiak, Bytów-Poznań 2001, s. 189-190. 
latach niepodległości reforma rolna i niski przyrost naturalny sprawiły, że państwo zaczęło dotkliwie odczuwać brak rąk do pracy. Pierwsi emigranci zarobkowi z Polski pojawili się na Łotwie pod koniec lat dwudziestych. Już w 1928 r. przedsiębiorstwa łotewskie przeprowadziły pierwszą rekrutację robotników w Polsce. Wolno sądzić, że przez Łotwę przewinęło się ponad 100 tysięcy polskich robotników rolnych ${ }^{2}$.

Analizując geografię pochodzenia emigrantów sezonowych na Łotwie należy stwierdzić, że na ogół pochodzili oni z różnych zakątków międzywojennego państwa polskiego, lecz prym zdecydowanie wiodły województwa wileńskie i nowogródzkie, z których pochodziła większość emigrantów ${ }^{3}$. Wśród polskich robotników rolnych na Łotwie przeważały młode kobiety w wieku 19-28 lat. Skład narodowościowy emigrantów był zróżnicowany. Zdecydowanie dominowali Polacy i Białorusini. Niemniej zdarzali się przedstawiciele innych grup narodowościowych (np. Litwini, Rosjanie) ${ }^{4}$.

Emigracja polskich robotników rolnych do Łotwy miała charakter sezonowy. Zazwyczaj sezon trwał 7-8 miesięcy: od połowy kwietnia do połowy listopada. Część emigrantów decydowała się na pozostanie na Łotwie w sezonie zimowym, obejmującym okres od połowy listopada do połowy kwietnia. Z upływem czasu coraz więcej robotników pozostawało na okres zimowy. W ten sposób emigracja zaczęła zatracać swój pierwotny charakter sezonowy i nabierała cech emigracji półstałej ${ }^{5}$. Pod koniec lat trzydziestych władze polskie uznały, że liczba emigrantów półsezonowych przewyższała liczebnie liczbę sezonowych. W ocenie polskiego MSZ w 1938 r. na Łotwie pracowało około 40 tys. polskich robotników sezonowych, z czego zakontraktowanych wiosną 1938 r. było jedynie ponad 17 tys. ${ }^{6}$

Polscy emigranci rolni stanowili w oczach Łotyszów swoistą wizytówkę Polski. Dlatego też wiedza o ich życiu codziennym może być cennym przyczynkiem do refleksji, jaki obraz Polski i Polaków ukształtował się wśród Łotyszów oraz pod wpływem jakich czynników on powstawał. W niniejszym

\footnotetext{
${ }^{2}$ P. ŁossowsKi, Lotwa nasz sasiad: stosunki polsko-łotewskie w latach 1918-1939, Warszawa 1990, s. 54.

${ }^{3}$ B. Kopeć, Wychodźstwo sezonowe z Ziemi Wileńskiej do Lotwy, Wilno 1938, s. 57.

${ }^{4}$ H. JANOwSKA, Emigracja zarobkowa z Polski 1918-1939, Warszawa 1981, s. 244.

${ }^{5}$ Archiwum Akt Nowych [dalej: AAN], MSZ, t. 9596, Referat Wydziału I MSZ w sprawie emigracji zarobkowej i sezonowej, 1939, k. 12.

${ }^{6}$ Lietuvos Centrinis Valstybès Archyvas [dalej: LCVA], f. 148, ap. 1, b. 856, Sprawozdanie i wnioski z wyjazdu do Łotwy w dn. 5-10 października 1938 r., na skutek delegacji Wileńskiej Izby Rolniczej; E. KoŁodZIEJ, Wychodźstwo zarobkowe z Polski 1918-1939. Studia nad polityka emigracyjna II Rzeczypospolitej, Warszawa 1982, s. 232.
} 
opracowaniu skupimy się na najważniejszych obszarach życia codziennego robotników.

\section{WARUNKI ŻYCIA I PRACY}

Warunki życia i pracy, w których znaleźli się robotnicy polscy po przybyciu do Łotwy i do których musieli się przystosować, były inne niż we własnym kraju. Przeciętne łotewskie gospodarstwo rolne było nieduże (10-30 ha), $\mathrm{w}$ związku z tym jeden gospodarz wiejski zatrudniał od jednego do trzech robotników sezonowych. W wyjątkowych sytuacjach zdarzało się, że było ich więcej - od pięciu do siedmiu. Czas pracy był regulowany według miejscowych zwyczajów, nie mógł jednak być dłuższy niż dla robotników łotewskich. Długość dnia pracy zależała od pory roku oraz rodzaju wykonywanej pracy. Często zdarzało się, iż w okresie od maja do sierpnia robotnicy musieli pracować po 12-13 godzin dziennie. W okresie żniw i wykopek dzień pracy rozpoczynał się o 4 lub 5 rano, a kończył się późno w nocy. Czas na odpoczynek wynosił więc zaledwie 4-5 godzin. Warunki pracy robotników sezonowych na Łotwie określały umowy o pracę (kontrakty) ${ }^{7}$. Kontrakt zawierał szczegółową informację w zakresie obowiązków robotników i pracodawców. Zgodnie z kontraktem robotnik miał wykonywać prace wskazane mu przez pracodawcę lub jego zastępcę i obchodzić się pieczołowicie z dobrem i narzędziami pracodawcy. Tymczasem pracodawca miał obowiązek zapewnić robotnikowi bezpłatne zakwaterowanie spełniające następujące kryteria: 1) zdrowe i ciepłe mieszkanie, 2) łóżko z siennikiem napełnionym czystym sianem lub słomą, kołdrę lub koc, prześcieradło i poduszkę. Kobiety i mężczyźni mieli mieszkać oddzielnie w warunkach nie gorszych niż robotnicy miejscowi. W praktyce jednak warunki mieszkaniowe były bardzo niejednolite. Czasem były to osobne izby w murowanych budynkach, ale nierzadko zdarzały się sytuacje, że robotnicy polscy gnieździli się po kilka osób na strychach lub w chlewach. Dość rozpowszechnionym zjawiskiem było umieszczanie kobiet i mężczyzn w jednym pomieszczeniu. Niektórzy pracodawcy, zatrudniając polskich emigrantów, nie przestrzegali zasad higieny, nie zapewniali pracownikom również środków czystości i przynajmniej jednego schludnego pokoju do mieszkania. Zdarzały się przypadki, że robotnicy otrzymywali łóżka bez pościeli lub pościel brudną, albo łóżka

\footnotetext{
${ }^{7}$ Komunikat Konsulatu RP w Rydze. Wysokość placy winna być wpisana do kontraktu, „Nasze Życie” 1939, nr 232, s. 15.
} 
dwuosobowe zamiast prycz. Pokoje z szafami zdarzały się bardzo rzadko. W 99\% oświetlenie mieszkania stanowiły lampy naftowe lub latarnie oborowe. Przeciętnie na 30 gospodarstw łotewskich w czterech nie było odpowiednich warunków do życia ${ }^{8}$.

Z badań ankietowych przeprowadzonych przez Instytut Gospodarstwa Społecznego wynikało, że 1/4 robotników polskich na Łotwie określiła warunki mieszkaniowe jako „złe”, „okropne” i „trudne do wytrzymania”. Ludwik Landau doszedł do wniosku, że skoro chłop polski, przyzwyczajony do bardzo skromnych i niehigienicznych warunków mieszkaniowych, narzeka na to, z czym się spotkał na Łotwie, świadczy to o rzeczywiście fatalnej sytuacji kwaterunkowej ${ }^{9}$. Ocena taka opierała się na analizie skarg robotników, którzy wrócili do Polski. Krytycznie wypowiadali się przede wszystkim ci emigranci, którzy jadąc do Łotwy mieli nieco wyidealizowane wyobrażenie na temat warunków bytowych panujących w tym kraju. Innego zdania byli przedstawiciele polskiej służby konsularnej. Pracownicy Konsulatu RP w Rydze, regularnie przeprowadzający inspekcję terenową, uważali, że warunki życia i pracy polskich robotników rolnych na Łotwie były do przyjęcia, a trwająca od lat emigracja sezonowa do Łotwy sprawiła, że robotnicy polscy przyzwyczaili się do miejscowych warunków życia i pracy ${ }^{10}$. W pewnym stopniu potwierdzają to również obserwacje delegata Wileńskiej Izby Rolniczej Romualda Węckowicza, który po odbyciu podróży do Łotwy uznał, że mimo pewnych wyjątków robotnicy polscy otrzymywali warunki nie gorsze od tych, które oni mieli u siebie $\mathrm{w}$ domu ${ }^{11}$.

Wysokość wynagrodzenia miesięcznego robotnika sezonowego była każdorazowo ustalana $\mathrm{w}$ czasie podpisania dwustronnej umowy na rok bieżący. Praca mężczyzn była nieco lepiej opłacana niż kobiet. W związku z tym, że coraz więcej robotników decydowało się na pozostanie za granicą w sezonie zimowy, poczynając od 1936 r. wprowadzono stawkę płac dla robotników pracujących w okresie od połowy listopada do połowy kwietnia. W okresie zimowym płace z natury rzeczy były niższe niż w lecie. Poniższa tabela ukazuje wysokość wynagrodzenia miesięcznego w walucie lokalnej polskich robotników rolnych na Łotwie w poszczególnych latach.

\footnotetext{
${ }^{8}$ B. Kopeć, Wychodźstwo sezonowe z Ziemi Wileńskiej..., s. 144.

${ }^{9}$ L. LANDAU, Wychodźstwo sezonowe na Łotwe $i$ do Niemiec w 1937 roku: na podstawie ankiety Instytutu Gospodarstwa, Warszawa 1966, s. 54-55.

${ }^{10}$ AAN, MSZ, t. 11606, Pismo Konsulatu RP w Rydze do MSZ, 13 IV 1939, k. 17.

${ }^{11}$ LCVA, f. 148, ap. 1, b. 856, Sprawozdanie i wnioski z wyjazdu do Łotwy w dn. 5-10 października 1938 r., na skutek delegacji Wileńskiej Izby Rolniczej.
} 
Tabela 1. Płace polskich robotników rolnych na Łotwie (w łatach)

\begin{tabular}{|c|c|c|c|}
\hline \multirow{2}{*}{ Rok } & \multicolumn{2}{|c|}{ W sezonie letnim } & \multirow{2}{*}{ W sezonie zimowym } \\
\cline { 2 - 3 } & Mężczyźni & Kobiety & \\
\hline 1935 & 23 & 18 & - \\
\hline 1936 & 24 & 20 & $18 / 17$ \\
\hline 1937 & 24 & 20 & $18 / 17$ \\
\hline 1938 & 36 & 31 & 26 \\
\hline 1939 & 40 & 35 & 30 \\
\hline
\end{tabular}

Źródło: Zmiany w kontraktach na rok 1936, „Nasze Życie” 1936, nr 64, s. 19; Кomunikat Konsulatu RP $w$ Rydze, „Nasze Życie” 1939, nr 216, s. 14; AAN, MSZ, t. 9689, Pismo Departamentu Konsularnego Wydziału Polityki Emigracyjnej MSZ do MOS, 7 II 1939, k. 22.

Ujęte w tabeli 1 dane pokazują te kwoty, które były wpisane do kontraktu. Jednak kontrakt określał jedynie dolną granicę wynagrodzenia. Natomiast pracodawca mógł według własnego uznania wypłacać robotnikowi wynagrodzenie wyższe niż to, które było przewidziane w kontrakcie ${ }^{12}$.

Badania wykazują, że 75\% mężczyzn i 87\% kobiet pracujących na Łotwie zarabiało w czasie sezonu letniego od 100 do 200 łatów. W przypadku mężczyzn było to od 150 do 200 łatów, zaś w przypadku kobiet - od 100 do 150 łatów. Dochód poniżej 100 łatów zdarzał się rzadko i dotyczył tych robotników, którzy z rozmaitych powodu musieli wcześniej wrócić do domu ${ }^{13}$. Płace zależały od regionu, w którym pracowano. Najniższe płace były w Łatgalii jako najbardziej zubożałym regionie kraju. W okresie wielkiego kryzysu płace zostały obniżone. W 1930 r. wynagrodzenie robotników rolnych na Łotwie spadło w Kurlandii o 3,4\% dla mężczyzn i o 2,7\% dla kobiet ${ }^{14}$.

Emigranci na ogół prowadzili dość oszczędny tryb życia, by móc przywieźć do domu jak najwięcej zarobionych pieniędzy. W 1937 r. przeciętnie emigranci zarobkowi wydali na Łotwie około 32 łatów. Po odliczeniu tej kwoty resztę zarobku robotnik sezonowy przekazywał do Polski. W przypadku rolnika z Wileńszczyzny przeciętnie było to około 127 łatów, z Nowogródczyzny - około 87 łatów, z pozostałych województw - od 60 do 70 łatów ${ }^{15}$.

\footnotetext{
12 Wyjaśnienie w sprawie kontraktów, „Nasze Życie” 1938, nr 172, s. 13.

${ }^{13}$ I. PALAŠA, Darbaspēka imparts Latvijas laukos starpkraru perioda, Magistra darbs, Rīga 2005, s. 87.

${ }^{14}$ Płace robotników rolnych $w$ Kurlandii, „Biuletyn Urzędu Emigracyjnego w Sprawach Migracji i Osadnictwa" 1930, nr 15, s. 176.

${ }^{15}$ L. LANDAU, Wychodźstwo sezonowe na Łotwę i do Niemiec w 1937 roku..., s. 112.
} 


\section{STOSUNKI Z PRACODAWCAMI ŁOTEWSKIMI}

Przebywający na Łotwie polscy emigranci zarobkowi przez większość czasu byli zajęci pracą w gospodarstwach, położonych z dala od większych miast. W związku z tym możliwości bliskiego kontaktowania ze społecznością miejscową były ograniczone. Na co dzień polski robotnik sezonowy miał styczność ze swoim pracodawcą i jego rodziną. Zgodnie z zasadami zawartymi w kontrakcie, pracodawca miał obowiązek otaczać robotnika opieką, w szczególności chronić robotnice przed niemoralnym obchodzeniem się z nimi współmieszkańców lub innych robotników, zatrudnionych u pracodawcy. Pracodawca zapewniał również robotnikowi dostęp do opieki lekarskiej ${ }^{16}$.

Tymczasem z przeprowadzonej w 1937 r. przez Instytut Gospodarstwa Społecznego ankiety wynika, że około połowy badanych emigrantów, którzy wrócili z Łotwy, uważała swoich gospodarzy za „złych”. Jednocześnie 1/3 robotników w stosunku do swojego pracodawcy użyła określenia „znośny” lub „możliwy”. Tylko 1/3 emigrantów uważała swoich pracodawców za dobrych ludzi. Analizując przyczyny nieporozumień powstających w relacjach pomiędzy robotnikami polskimi a pracodawcami łotewskimi, warto przyjrzeć się skargom emigrantów przesłanym do konsulatu RP w Rydze w roku 1935 i 1936. Można je podzielić na następujące kategorie: dotyczące wynagrodzenia za płace (31\% i 32\%), złego wyżywienia (19\% i 21\%), złego traktowania (16\% i 18\%), złych warunków mieszkaniowych (11\% i 12\%), zbyt ciężkiej pracy $(10 \%)$, pobicia przez pracodawców ( $2 \%$ i $3 \%$ ), niemoralnego zachowania się pracodawców ( $1 \%$ i $2 \%)^{17}$. W przypadku konfliktów z pracodawcą emigranci posiadali trzy możliwości: 1) zwrócić się na policję, 2) zwrócić się do konsulatu RP i 3) pozwać pracodawcę do sądu ${ }^{18}$.

Częstą przyczyną niezadowolenia robotników było to, że pracodawcy interpretowali poszczególne przypisy kontraktu na niekorzyść robotników oraz nie przestrzegali postanowień umowy. Niektórzy zarzucali gospodarzom łotewskim, że byli przez nich zmuszani do ciężkiej pracy. Uzasadniali to m.in. w ten sposób:

\footnotetext{
${ }^{16}$ Dziarżaŭny archiŭ Hrodzienskaj voblasci [dalej: DAHV], F. 551, vop. 1, spr. 1340, Umowa o pracę dla polskich robotników rolnych w Łotwie na rok 1939, 1. 3.

${ }^{17}$ B. KoPeć, Wychodźstwo sezonowe z Ziemi Wileńskiej ..., s. 138, 139.

${ }^{18}$ DAHV, F. 551, vop. 1, spr. 1340, Umowa o pracę dla polskich robotników rolnych w Łotwie na rok 1939, 1. 2-3.
} 
Ganiał i popędzał do pracy, że ani chwili wytchnienia nie dawał, ciągle mu było mało, a jak my nie chcieli, to wymyślał od polskiego bydła, polskich świń, że my nie na spacer do Łotwy przyjechali, tylko na robotę ${ }^{19}$.

Według niektórych robotnic gospodarze zlecali im pracę, do której się nie nadawały (np. koszenie trawy, obrządzanie koni) ${ }^{20}$. Niektórzy emigranci wylewali swoje żale w sposób szczególnie emocjonalny, przez co można było odnieść wrażenie, że ich sytuacja nosiła znamiona niewolnictwa ${ }^{21}$.

Jednak do tych negatywnych opinii robotników należy odnosić się z dużą rezerwą. Nie mogą one być miernikiem stosunku wszystkich emigrantów do gospodarzy łotewskich, bowiem wyrażają poglądy tylko pewnej grupy. Część powyższych narzekań nie znajdowała potwierdzenia w rzeczywistości, a za niektóre nieporozumienia ponosili winę sami emigranci, co zresztą przyznawała strona polska ${ }^{22}$. Z obserwacji polskich pracowników konsularnych wynikało, że nieraz robotnicy jako ludzie niewykształceni i nieobyci z realiami panującymi w obcym kraju, na skutek nieznajomości swoich praw, własnej opieszałości lub niedbalstwa, sami stawiali się w złej sytuacji ${ }^{23}$. W wielu przypadkach zażalenia robotników nie znajdowały pokrycia w rzeczywistości, a uwagi i skargi na pracodawców były niezasadne i mijały się z prawdą. Zarzuty o złe traktowanie pod adresem pracodawców były przejaskrawione i wyolbrzymione ${ }^{24}$. Negatywne opinie emigrantów nie dają pełnego obrazu sytuacji, bowiem najczęściej dotyczyło to tych robotników, którzy z rozmaitych powodów przedwcześnie powrócili do kraju. Postępowało tak blisko $10 \%$ robotników rolnych rocznie. W tym samym czasie na Łotwie przebywały tysiące innych robotników polskich, którzy spędzali tam po kilka lat, rokrocznie przedłużając umowy na kolejne sezony. Stanowi to dowód, że ludzie ci byli zadowoleni z warunków pracy, a stosunki pomiędzy nimi i zatrudniającymi ich Łotyszami układały się pomyślnie.

\footnotetext{
${ }^{19}$ L. LANDAU, Wychodźstwo sezonowe na Łotwe i do Niemiec w 1937 roku..., s. 60.

${ }^{20}$ AAN, MSZ, t. 11606, Pismo Konsularnego Wydziału Opieki Prawnej, 10 V 1939, k. 45.

${ }^{21}$ AAN, List byłego polskiego robotnika polskiego na Łotwie do Polskiego Komitetu Walki z Handlem Kobietami i Dziećmi, 1938, k. 302.

${ }^{22}$ Nasze porady i odpowiedzi, „Nasze Życie” 1938, nr 176, s. 14.

${ }^{23}$ Konsul RP w Daugawpilsie T. Buynowski odwiedza robotników, „Nasze Życie” 1936, nr 82, s. 14.

${ }^{24}$ VIII-my komunikat Konsulatu RP w Rydze, „Nasze Życie” 1937, nr 142, s. 18; Konsul RP w Rydze St. Ryniewicz wśród robotników, „Nasze Życie” 1938, nr 189, s. 13; AAN, MOS, t. 89, Pismo Konsulatu RP w Rydze do MSZ, 9 III 1933, k. 4-5; LCVA, f. 156, ap. 1, b. 79, Pismo Konsula RP w Rydze do Departamentu Konsularnego MSZ, 17 VIII 1932.
} 
Powstawaniu potencjalnych konfliktów sprzyjał fakt, że większość robotników sezonowych podejmowała pracę za każdym razem u nowego gospodarza. Emigranci nie trzymali się zatem kurczowo jednego pracodawcy. Gospodarze łotewscy również nie stanowili jednolitej grupy pod względem traktowania robotników. W rzeczywistości wiele zależało od tego, do jakiego pracodawcy trafiał robotnik lub robotnica. W przypadku, gdy robotnik trafił do nieuczciwego pracodawcy, traktującego go źle lub obarczającego nadmierną pracą, nie mógł natychmiastowo się przenieść do innego gospodarza ${ }^{25}$.

$\mathrm{Na}$ wzajemne postrzeganie robotników polskich i gospodarzy łotewskich wpływ miały również pewne różnice w podejściu do organizacji pracy. Stosunek łotewskich gospodarzy do pracy trafnie ujął Bohdan Kopeć. Według niego gospodarze łotewscy byli pracowici, oszczędni i surowi zarówno w stosunku do siebie samych, jak i podwładnych. Cechy te miały bezpośredni wpływ na relacje między nimi a robotnikami polskimi. Przeciętny gospodarz łotewski, który zatrudniał robotników polskich, nie pochodził z rodziny ziemiańskiej, lecz był zwykłym chłopem, zazwyczaj pracującym wraz z robotnikiem w polu. Gospodarze łotewscy byli bardzo pracowici i wytrzymali fizycznie i tego samego wymagali od swoich robotników. Osobisty udział gospodarza we wszystkich pracach $w$ gospodarstwie zmuszał robotnika do większego wysiłku. Jeżeli się okazało, że robotnik nie akceptuje obowiązujących zasad, gospodarz bez najmniejszych skrupułów mógł się go pozbyć. Robotnicy polscy musieli więc dokładać wszelkich starań, by przystosować się do nowych warunków pracy ${ }^{26}$. Nie wszyscy byli w stanie sprostać temu zadaniu. $\mathrm{Z}$ obserwacji łotewskiej policji politycznej wynikało, że robotnicy polscy nie byli przyzwyczajeni do dyscypliny i intensywności tamtejszej pracy. Mając inne standardy u siebie w kraju, niekiedy buntowali się przeciwko zasadom, jakie funkcjonowały w miejscowych gospodarstwach rolnych, a ci najbardziej zdesperowani po kilku dniach nawet porzucali pracę i wracali do Polski ${ }^{27}$.

U podstaw niektórych konfliktów leżały przyczyny psychologiczne. Pamiętajmy, że większość emigrantów nigdy wcześniej nie opuszczała rodzinnych stron, a po wyjeździe z kraju nagle znalazła się w zupełnie nowej rzeczywistości. Obce otoczenie, inna kultura i język, tęsknota za domem - wszystko to wpływało na psychikę i wywoływało frustracje. Oddajmy głos robotnikowi Mikołajowi Sciepulonkowi:

\footnotetext{
${ }^{25}$ B. Kopeć, W sprawie emigracji sezonowej do Łotwy, ,Tygodnik Rolniczy” 1939, nr 1-2, s. 5.

${ }^{26}$ B. Kopeć, Wychodźstwo sezonowe z Ziemi Wileńskiej..., s. 145.

${ }^{27}$ A. Stranga, Kārḷa Ulmaņa autoritatīvā režīma saimnieciskā politika 1934-1940, Rīga 2017, s. 76
} 
Brak mi słów do wyrażenia smutku, który panował we mnie w pierwszych dniach mego pobytu w Łotwie, gdyż trafiłem do gospodarza zamieszkałego nad granicą litewską, gdzie prawie wszyscy robotnicy byli z Litwy, nie umiejący mówić ani po polsku, ani po rosyjsku. Myśl mnie dusiła: uciekać! Lecz dokąd? ${ }^{28}$

Jeśli chodzi o zdolności do przystosowania się do miejscowych warunków i tempa pracy, zarysowywały się pewne różnice pomiędzy robotnikami z Wileńszczyzny i Nowogródczyzny a robotnikami pochodzącymi z centralnych i południowych części Polski. Badania Ludwika Landaua dowodzą, że pierwsi nie stawiali pracodawcom wygórowanych wymagań, a czasami nie domagali się nawet standardu przewidzianego w kontrakcie. Przeważna większość robotników z Wileńszczyzny i Nowogródczyzny z reguły nie przerywała pracy przed końcem sezonu. Przypadki przedwczesnych powrotów wśród nich zdarzały się rzadko (w 1937 r. tylko 3\%), przy czym były one na ogół spowodowane złym stanem zdrowia. Emigracja zarobkowa z Wileńszczyzny do Łotwy miała dłuższą tradycję, a więc emigranci dość dobrze orientowali się, jakie warunki ich czekają i byli na nie przygotowani. Robotnicy z Wileńszczyzny sprawnie dostosowywali się do miejscowych warunków i nie dość, że nie zrywali kontraktów, to jeszcze przejawiali chęć pozostania na Łotwie w sezonie zimowym. Innymi przesłankami kierowali się robotnicy sezonowi z innych części Polski - z województw białostockiego, łódzkiego, kieleckiego, lwowskiego. W grupie tej znajdowali się ludzie, którzy wcześniej powrócili z Niemiec, gdzie pracowali jako robotnicy sezonowi. Mogli więc porównać warunki pracy istniejące na Łotwie z tymi, które panowały w Niemczech. Emigranci ci skarżyli się na złe traktowanie i ciężkie warunki pracy. Pytani, czy chcieliby w przyszłości znów wyjechać do pracy za granicę, odpowiadali, że tak, ale nie do Łotwy ${ }^{29}$.

W kontaktach z pracodawcą robotnicy polscy przeważnie posługiwali się językiem rosyjskim. Był on stosunkowo dobrze znany zarówno przez gospodarzy łotewskich, jak i robotników polskich pochodzących z byłego zaboru rosyjskiego. Nieprzypadkowo w czasie rekrutacji strona łotewska preferowała osoby w mniejszym lub większym stopniu władające tym językiem ${ }^{30}$. O ile

\footnotetext{
${ }^{28}$ Listy... Listy, „Nasze Życie” 1937, nr 110, s. 18.

${ }^{29}$ Latvijas Valsts vēstures arhīvs [dalej: LVVA], 3219 f., 1 apr., 12662 1., List Konsulatu RR w Rydze do Tatiany Korniłowicz, 24 VIII 1937, 1 1; LCVA, f. 156, ap. 1, b. 69, Pismo Konsulatu RP w Rydze od PUPP w Wilnie w sprawie Mariana Kisiela i Nikandra Dubczonka, b/d; L. LANDAU, Wychodźstwo sezonowe na Łotwę i do Niemiec w 1937 roku..., s. 48-49.

${ }^{30}$ LCVA, f. 156, ap. 1, b. 79, Pismo UE do Lotewskiego Centralnego Towarzystwa Rolniczego, 1931.
} 
emigranci ze wschodniej Polski dobrze posługiwali się tym językiem, o tyle robotnicy pochodzący z województw centralnych i południowych mieli z nim kłopot. $\mathrm{Z}$ tego powodu, po kilkudniowym zaledwie pobycie na Łotwie, musieli wracać do kraju, bo zrozpaczeni pracodawcy wypowiedzieli im umowy ${ }^{31}$. W miejscowościach mieszanych narodowościowo (np. w Łatgalii i powiecie iłłuksztańskim) językiem porozumiewania się między robotnikami a pracodawcami mógł być język polski lub gwara polsko-białoruska, którą w jednakowym stopniu posługiwały się obie strony. Historia dostarcza nam przykładów, że niektórzy emigranci stopniowo opanowywali język łotewski w stopniu pozwalającym im na w miarę swobodne porozumiewanie się z pracodawcami, zwłaszcza na tematy związane $\mathrm{z}$ wykonywaną pracą. W szczególności dotyczyło to robotników, którzy spędzili na Łotwie więcej niż jeden sezon.

\section{3. ŻYCIE RELIGIJNE}

Pod względem wyznaniowym na Łotwie dominował protestantyzm, podczas gdy emigranci polscy byli w większości katolikami, prawosławnymi i staroobrzędowcami. Co prawda, na Łotwie występowały zwarte skupiska ludności katolickiej, prawosławnej i staroobrzędowej, lecz znajdowały się one $\mathrm{w}$ Łatgalii położonej poza zasięgiem głównego terenu migracyjnego w tym kraju. Emigranci mieli więc utrudniony regularny dostęp do udziału w nabożeństwach. Władzom RP wespół ze zwierzchnikami Kościoła katolickiego w Polsce zależało, by emigranci wyznania katolickiego mogli brać czynny udział w życiu religijnym. Sprawę tę traktowano jak coś więcej, niż tylko zaspokojenie potrzeb religijnych własnych obywateli. Widziano w tym narzędzie podtrzymania ducha narodowego i tożsamości polskiej. W tym celu dbano także, by emigranci mieli kontakt przede wszystkim $\mathrm{z}$ duchowieństwem polskim $^{32}$. W prasie polskiej na Łotwie regularnie zamieszczano informacje na temat możliwości uczęszczania na nabożeństwa, celebrowane przez księży Polaków. Pracę duszpasterską wśród emigrantów prowadziło czterech polskich duchownych, urzędujących w miejscowościach Cesis, Sigulda, Jelgava i Valmiera. Księża ci wyjeżdżali do innych miejscowości w celu odprawiania nabożeństw dla robotników sezonowych ${ }^{33}$. Natomiast

\footnotetext{
${ }^{31}$ LCVA, f. 148, ap. 1, b. 856, Sprawozdanie z działalności Punktu Sanitarno-Zbiorczego PCK w Turmoncie w okresie od 1 kwietnia do 16 kwietnia 1934.

${ }^{32}$ Opieka duszpasterska nad emigracja polska, „Biuletyn Urzędu Emigracyjnego w Sprawach Migracji i Osadnictwa" 1929, nr 17, s. 141.

${ }^{33}$ Nabożeństwa katolickie dla robotników rolnych, „Nasze Życie” 1939, nr 216, s. 14.
} 
strona łotewska wolała, by polscy robotnicy rolni byli obsługiwani przez miejscowe duchowieństwo łotewskie. W tym celu w 1937 r. w Pētemiekach (20 km od Jelgavy) zbudowano kościół, w którym nabożeństwa celebrował ks. Leon Kundziņš, mianowany przez metropolitę ryskiego na kapelana robotników rolnych ${ }^{34}$.

W 1938 r. polskie MSZ uznało, że do Łotwy należy sprowadzić więcej księży Polaków, którzy mogliby roztoczyć opiekę duszpasterską nad polskimi robotnikami sezonowymi ${ }^{35}$. Forsowanie przez stronę polską możliwości zapewnienia emigrantom opieki duszpasterskiej przez duchownych Polaków nie wynikało wyłącznie $\mathrm{z}$ dążenia do zaspokojenia potrzeb duchownych robotników sezonowych. Sprawa ta miała szerszy kontekst polityczno-narodowościowy. Na Łotwie znajdowała się dość liczna mniejszość polska (około 50 tys.), która była wyznania katolickiego. Władze w Rydze dokładały wszelkich starań, by tradycyjnie mocne wpływy polskie zastąpić w kościele łotewskimi ${ }^{36}$. Tymczasem władze $\mathrm{w}$ Warszawie obawiały się, że relegowanie polszczyzny z kościoła doprowadzi do wynarodowienia ludności polskiej w Łatgalii ${ }^{37}$. Władze łotewskie starały się nie wydawać zgody na przyjazd nowych duchownych z Polski w celu prowadzenia działalności duszpasterskiej wśród miejscowych Polaków. Tymczasem umowa emigracyjna otwierała takie możliwości pod pretekstem pracy duszpasterskiej wśród robotników sezonowych. W Warszawie zakładano, że księża przysłani z Polski, mający prowadzić posługę wśród robotników sezonowych, będą mogli przy sposobności prowadzić ostrożną działalność duszpasterską wśród rdzennej ludności polskiej na Łotwie ${ }^{38}$. Wybuch II wojny światowej nie pozwolił jednak urzeczywistnić tych planów.

Analiza dostępnych źródeł pozwala wysnuć wniosek, że frekwencja robotników na nabożeństwach na Łotwie pozostawiała wiele do życzenia. Wielu emigrantów w ogóle nie chodziło do kościoła z powodu braku wolnego czasu i dużej odległości od miejsca pracy, gdyż sieć parafii katolickich w tym kraju (z wyjątkiem dawnych Inflantów Polskich) była stosunkowo

${ }^{34}$ I. PALAŠA, Darbaspēka imparts Latvijas laukos..., s. 98.

${ }^{35}$ AAN, MSZ, t. 11581, Porozumienie między Ministerstwem Opieki Społecznej Rzeczypospolitej Polskiej a Ministerstwem Rolnictwa Republiki Łotewskiej w sprawie polskich robotników rolnych, sezonowych i innych, 29 X 1938, k. 20.

${ }^{36}$ A. Skrzypek, Stosunki polsko-łotewskie 1918-1939, Gdańsk 1997, s. 113; J. Albin, Polski ruch narodowy na Eotwie w latach 1919-1940, Wrocław 1994, s. 191-192.

${ }^{37}$ AAN, MSZ, t. 10475, Szkolnictwo polskie na Łotwie, 1938, k. 15.

${ }^{38}$ AAN, MSZ, t. 10474, Notatka Wydziału II w sprawie rokowań polsko-łotewskich, 21 II 1938, k. 10. 
rzadka $^{39}$. Z prawnego punktu widzenia w niedziele i święta robotnik mógł wykonywać tylko niezbędne prace domowe i przy obrządzaniu żywego inwentarza. Robotnikowi należała się jedna wolna niedziela w miesiącu, a dniami wolnymi od pracy były święta katolickie - Wniebowstąpienie Pańskie i Wniebowzięcie $\mathrm{NMP}^{40}$. Mimo to zdarzało się, że gospodarze niechętnie zwalniali robotników na nabożeństwa. Na przykład robotnica M. Maciejonok opisywała sytuację, kiedy to pracodawca-adwentysta kazał jej pracować w niedzie$1 e^{41}$. Niektórzy emigranci twierdzili, że byli świadkami drwin z religii katolickiej, co obrażało ich uczucia religijne ${ }^{42}$. W niektórych przypadkach to nie postawa pracodawców decydowała o niskiej aktywności religijnej emigrantów. Część robotników wolała w niedziele pracować zamiast uczestniczyć w nabożeństwach. Przemawiały za tym względy ekonomiczne, bowiem za pracę $\mathrm{w}$ polu $\mathrm{w}$ niedzielę lub święta robotnik otrzymywał wynagrodzenie w wysokości dwudniowej stawki ${ }^{43}$.

Zabiegi państwa polskiego mające na celu zapewnienie robotnikom polskim na Łotwie należytej opieki duszpasterskiej w języku polskim ograniczały się jedynie do wyznania katolickiego. Nie wykazywano większego zainteresowania sprawami robotników innych wyznań, dlatego też niewiele wiemy na temat ich życia religijnego. Można jedynie przypuszczać, że przynajmniej część z nich uczęszczała na nabożeństwa do miejscowych parafii prawosławnych i staroobrzędowskich. Na Łotwie istniała sieć parafii obu tych wyznań, lecz skupiały się one głównie w Łatgalii, gdzie przebywało stosunkowo niewielu polskich robotników sezonowych. W pozostałej części kraju świątynie prawosławne znajdowały się w niektórych dużych miastach. Należy przypuszczać, że duże odległości oraz rzadka sieć tych parafii uniemożliwiały jednak regularny udział robotników w nabożeństwach.

\section{SPRAWY DAMSKO-MĘSKIE}

Pobyt za granicą nie pozostał bez wpływu na zmiany obyczajowości wielu emigrantów. W szczególności dotyczy to zachowania seksualnego robotników

${ }^{39}$ Z. STANKIEWICZ, Życie spoleczno-religijne Polaków na Lotwie w okresie międzywojennym (1920-1940), [w:] Polacy na Lotwie, red. E. Walewander, Lublin 1993, s. 186.

${ }^{40}$ DAHV, F. 551, vop. 1, spr. 1340, Umowa o pracę dla polskich robotników rolnych w Łotwie na rok 1939, 1. 2-3.

${ }^{41}$ Nasze porady i odpowiedzi, „Nasze Życie” 1939, nr 222, s. 14.

${ }^{42}$ L. LANDAU, Wychodźstwo sezonowe na Łotwę i do Niemiec w 1937 roku ..., s. 134.

${ }^{43}$ Stary BartŁomiej, Echa wypadków w Walmiera, „Nasze Życie” 1938, nr 192, s. 14. 
i robotnic. Osamotnienie i potrzeba stworzenia bliskich relacji oraz łatwość nawiązywania stosunków towarzyskich, wynikająca $\mathrm{z}$ warunków mieszkaniowych, ułatwiały rozwiązłość seksualną wielu młodych ludzi ${ }^{44}$. Efektem przypadkowych kontaktów seksualnych były często niezaplanowane ciąże młodych robotnic. Incydentów tych nie można jednak ująć statystycznie. Nie zmienia to faktu, że nie było to zjawisko marginalne i jednostkowe. Dostrzegali je zarówno przedstawiciele władz, jak i opinia publiczna. Znawca zagadnienia Bohdan Kopeć twierdził, że

wystarczy wyjechać na te wsie i okolice w pow. brasławskim, z których najwięcej ludności wyjeżdża do Łotwy, aby przekonać się jak bardzo zwiększa się tam „przyrost naturalny”, jak w każdej prawie wsi znaleźć można przynajmniej jedno dziecko nieślubne, przywiezione z Łotwy ${ }^{45}$.

W większości przypadków ojcami tych dzieci byli polscy robotnicy sezonowi, rzadko - miejscowi ${ }^{46}$. Utrzymanie nieślubnych dzieci robotnic spoczywało na barkach polskiej służby konsularnej, ponieważ pociechy były umieszczane w żłobkach łotewskich na koszt skarbu państwa polskiego. Utrzymanie ich stawało się uciążliwe dla państwa polskiego. Na opłaty za żłobki wydano $58 \%$ wszystkich funduszy pomocy społecznej, którymi dysponował Konsulat RP w Rydze ${ }^{47}$. Polska służba konsularna zdecydowała ostatecznie o odsyłaniu dzieci do Polski. Przemawiały za tym nie tylko względy ekonomiczne. Polskie MSZ uznało, że repatriacja uchroni te dzieci przed asymilacją ${ }^{48}$. Na początku 1938 r. Konsulat RP w Rydze, w porozumieniu z władzami wojewódzkimi, zorganizował zbiorowy transport nieślubnych dzieci, które przebywały na koszt państwa w żłobkach łotewskich ${ }^{49}$. „Efektem rozwiązłości seksualnej robotnic, poza nieślubnymi dziećmi, bywały sytuacje, w których kobiety te padały ofiarą oszustwa lub grabieży. Lekkomyślność i niefrasobliwość robotnic często wykorzystywali uwodziciele, którzy je okradali" ${ }^{, 0}$.

\footnotetext{
${ }^{44}$ LVVA, 3219 f., 1 apr., 18081 1., Akta Jana Butkiewicza; L. LANDAU, Wychodźstwo sezonowe na Łotwę i do Niemiec w 1937 roku..., s. 80.

${ }^{45}$ B. Kopeć, $W$ sprawie emigracji sezonowej do Łotwy..., s. 5.

${ }^{46}$ AAN, MSZ, t. 11568, Pismo Konsulatu RP w Rydze do wileńskiego urzędu wojewódzkiego w sprawie repatriacji nieślubnych dzieci z Łotwy, 25 X 1937, k. 138.

${ }^{47}$ AAN, MSZ, t. 11568, Pismo Konsulatu RP w Rydze do MSZ, 24 V 1937, k. 37.

${ }^{48}$ AAN, MSZ, t. 11568, Sprawozdanie z kontroli rachunków za opiekę nad obywatelami polskimi oraz za leczenie polskich robotników rolnych na Łotwie w roku 1936, k. 151.

${ }^{49}$ Komunikat Konsulatu RP w Rydze, „Nasze Życie” 1938, nr 167, s. 14.

${ }^{50}$ Jeszcze jedna ofiara własnej naiwności, „Nasze Życie” 1937, nr 116, s. 18; Znowu nieostrożność, „Nasze Życie” 1937, nr 110, s. 18.
} 
Co było przyczyną rozwiązłości seksualnej młodych robotników i robotnic? Ludwik Landau uważał, że sprzyjał temu przede wszystkim fakt wyswobodzenia się młodzieży wiejskiej spod wpływu opinii publicznej własnej wsi. Elementem, który wpływał na kształtowanie się nowych kryteriów moralności, był sam fakt oderwania się od rodzimego środowiska społecznego, którego opinia narzucała młodym ludziom silne hamulce psychologiczne. Ponadto emigranci zetknęli się z nowym otoczeniem i nowymi normami postępowania. Nie bez znaczenia był tu wpływ bardziej zmaterializowanego społeczeństwa łotewskiego. Również brak stałych praktyk religijnych skutkował osłabieniem uczuć religijnych, a w konsekwencji zmianami obyczajowymi. Na przykład stosunki pozamałżeńskie, uznawane dawniej za niedopuszczalne i skutkujące ostracyzmem społecznym, przestawały być czymś haniebnym ${ }^{51}$.

Błędem byłoby jednak założenie, że wszystkie związki intymne kończyły się rozstaniem i osobistą tragedią. Zdarzały się sytuacje, gdy robotnicy zawierali związki małżeńskie. W większości śluby odbywały się między emigrantami. Robotnicy i robotnice z różnych powiatów Polski, pracujący u jednego gospodarza, mieli okazję, by się nawzajem poznać. Rzadziej zdarzały się małżeństwa mieszane, przy czym częściej Polki wychodziły za mąż za Łotyszów, niż Polacy żenili się z miejscowymi dziewczynami ${ }^{52}$. Historia wymienia przykłady pracodawców zabiegających o względy zatrudnionych u nich robotnic polskich ${ }^{53}$.

\section{CZAS WOLNY I ROZRYWKI}

Praca w gospodarstwach nie wypełniała całego czasu robotników spędzanego za granicą. Niewątpliwie mieli oni dni wolne, np. niedziele i święta. Spędzali je różnie, w zależności od sytuacji i własnych preferencji. Oderwanie od rodzin, niski poziom kulturowy i ciężka, stresująca praca sprawiały, że często podstawowym sposobem spędzania wolnego czasu było picie alkoholu i imprezowanie. Minister spraw publicznych Łotwy Alfreds Bērziņš uważał, że to właśnie polscy robotnicy rolni na ogół byli elementem zakłócającym spokojne życia wsi łotewskiej ${ }^{54}$. Zdarzały się bowiem przypadki, kiedy robotnicy urządzali huczne imprezy, co wywoływało niezadowolenie

\footnotetext{
${ }^{51}$ L. LANDAU, Wychodźstwo sezonowe na Lotwę i do Niemiec w 1937 roku ..., s. 78, 79.

${ }^{52}$ LVVA, 3219 f., 1 apr., 14562 1., Akta Kazimierza i Antoniny Bejnor, 1 lpp.

${ }^{53}$ Sprawa obywatelstwa przy zawarciu matżeństwa, „Nasze Życie” 1936, nr 67, s. 19.

${ }^{54}$ A. Stranga, Kārḷa Ulmaṇa autoritatīiā režīma saimnieciskā politika ..., s. 76.
} 
społeczności lokalnej. W związku z tym w czerwcu 1938 r. Konsulat RP wydał komunikat informujący, że przed urządzeniem zabawy należy uprzednio uzyskać na to zezwolenie od właściwej administracji publicznej ${ }^{55}$. Nadużycia alkoholu były najczęstszą przyczyną przykrych incydentów, do których dochodziło z udziałem emigrantów. Niestety, niemożliwe jest ustalenie skali tego zjawiska. Dysponujemy jednak dość licznymi przykładami, które pozwalają wywnioskować, że różne incydenty z udziałem robotników polskich miały miejsce ${ }^{56}$. Najgłośniejsze $z$ nich przedostały się do miejscowej prasy. Głos zabierał również Konsulat RP w Rydze, który niejednokrotnie wystosowywał apele do robotników nawołując ich do zachowania zdrowego rozsąd$\mathrm{ku}^{57}$. W przypadku niemal wszystkich incydentów sprawcami byli emigranci, którzy działali pod wpływem alkoholu. Analiza powyższych wypadków wskazuje, że robotnicy byli zarówno ofiarami, jak i sprawcami awantur i morderstw, natomiast ludność miejscowa występowała w roli zewnętrznych świadków i obserwatorów. Odnotowano tylko kilka przypadków, w których ofiarami napadów lub oszustwa byli miejscowi ${ }^{58}$. Nieprzypadkowo w polskim MSZ pojawiały się głosy ubolewania, iż emigracja sezonowa w oczach obcych nadwyręża wizerunek i reputację państwa polskiego ${ }^{59}$.

Jednak nie ma podstaw, by twierdzić, że takie postawy dominowały wśród robotników. Nie ma również żadnych dowodów na to, że obecność Polaków wpłynęła na stan przestępczości na Łotwie. Jest rzeczą naturalną, że w tak licznej grupie ludzi przykre incydenty były nieuniknione. Wszakże zdecydowana większość robotników sumiennie pracowała, nie wdając się w awantury i nie stwarzając żadnych problemów sobie i otoczeniu. Co więcej, niektórzy robotnicy otwarcie potępiali zachowanie kolegów dopuszczających się niecnych czynów ${ }^{60}$.

Niektórzy emigranci czas wolny od pracy spędzali na czytaniu lub brali udział w życiu kulturalnym. Władze polskie podejmowały starania, by

${ }^{55}$ Komunikat Konsulatu RP $w$ Rydze, „Nasze Życie” 1938, nr 183, s. 13.

${ }^{56}$ LVVA, 3219 f., 1 apr., 6090 1., Akt zgonu Józefy Korolko z domu Obolewicz, 27 VI 1939; Komunikat Konsulatu RP w Rydze, „Nasze Życie” 1938, nr 197, s. 13; Stuszna kara, „Nasze Życie” 1938, nr 198, s. 14; Komunikat Konsulatu RP w Rydze, „Nasze Życie” 1938, nr 197, s. 13; Uprzedzamy: bąd́cie ostrożni, „Nasze Życie” 1936, nr 103, s. 18.

${ }^{57}$ Komunikat Konsulatu RP $w$ Rydze. Do sumienia i poczucia obywatelskiego robotnika, „Nasze Życie” 1938, nr 191, s. 13.

${ }^{58}$ AAN, MSZ, t. 11606, Pismo posła F. Charwata do MSZ, XI 1937, k. 368.

${ }^{59}$ AAN, MSZ, t. 9896, Protokół z posiedzenia Międzyministerialnej Konferencji Emigracyjnej, 25 II 1938, k. 10.

${ }^{60}$ Stary BARTŁOMIEJ, Echa wypadków w Walmiera, „Nasze Życie” 1938, nr 192, s. 14; BAZYL, Z niebieskiej teczki, „Nasze Życie” 1939, nr 226, s. 15. 
zapewnić robotnikom kontakt ze słowem drukowanym w języku ojczystym. Uważano to za rzecz bardzo wskazaną, bowiem z dala od ojczyzny emigranci łatwo mogli ulec demoralizacji i wynarodawianiu. W latach trzydziestych w Rydze ukazywał się tygodnik „Nasze Życie”, który był finansowo wspierany przez Konsulat RP w Rydze. Zaczynając od 1936 r., gazeta posiadała specjalny „Kącik polskiego robotnika rolnego”, w którym udzielano emigrantom praktycznych rad i wskazówek. Na początku liczba odbiorców gazety wśród emigrantów była nieznaczna. Redakcja jednak nie ustawała w wysiłkach, by pozyskać jak największą liczbę czytelników wśród robotników sezonowych. W tym celu uciekano się do reklamy i różnych ofert rabatowych ${ }^{61}$. Redakcja wysyłała odpłatnie swoim czytelnikom kalendarze i inną literaturę. Zachęcając robotników do prenumerowania, redakcja odwoływała się do uczuć patriotycznych pisząc, że „pismo polskie w ręku robotnika polskiego, to pierwszy znak jego świadomej polskości; dowód, że tej polskości się nie wstydzi ani obawia" ${ }^{2}$.

Akcję na rzecz zwiększenia popularności gazety prowadziły również władze polskie. Konsulat RP w Rydze apelował do robotników o czytanie i prenumerowanie pisma, podkreślając jego zalety i pożyteczność ${ }^{63}$. W kwietniu 1938 r. Konsulat RP w Rydze wyróżnił dwóch robotników sezonowych G. Sachara i P. Puzyrewskiego za pomoc w rozpowszechnianiu tygodnika „Nasze Życie”. Robotnicy ci otrzymali w nagrodę książkę o treści historyczno-religijnej Bóg i Ojczyzna wraz z ilustrowanym kalendarzem książkowym na rok $1938^{64}$. Latem 1938 r. jedenastu robotników otrzymało książki o marszałku Edwardzie Rydzu-Śmigłym wraz z dedykacją konsula Ryniewicza ${ }^{65}$.

Działania redakcji i Konsulatu RP przyniosły pewne rezultaty. Na początku 1939 r. liczba stałych abonentów pisma wzrosła do 1626 osób, wśród których aż 1074 stanowili robotnicy sezonowi ${ }^{66}$. W rzeczywistości gazeta trafiała do większej liczby osób, ponieważ często robotnicy nieprenumerujący pisma pożyczali go od kolegów ${ }^{67}$. Niektórzy robotnicy stawali się gorliwymi kolporterami gazety wśród swoich rodaków. Inni aktywnie przesyłali

\footnotetext{
${ }^{61}$ Rozpowszechniajcie „Nasze Życie”, ,Nasze Życie” 1936, nr 74, s. 14.

${ }^{62}$ Stary BartŁomiej, Po raz ostatni, „Nasze Życie” 1939, nr 217, s. 15.

${ }^{63}$ Komunikat Konsulatu RP w Rydze, „Nasze Życie” 1938, nr 167, s. 14; List otwarty konsula RP w Rydze Stefana Ryniewicza, „Nasze Życie” 1936, nr 83, s. 14.

${ }^{64}$ Tu Konsulat RP w Rydze, „Nasze Życie” 1938, nr 173, s. 14; Lipiec-miesiacem propagan$d y$ „,Naszego Życia”, ,Nasze Życie” 1938, nr 188, s. 13.

${ }^{65}$ Nagrody dla tych, którzy propaguja „,Nasze Życie”, „Nasze Życie” 1938, nr 191, s. 14.

${ }^{66}$ J. Albin, Polski ruch narodowy na Łotwie..., s. 190.

${ }^{67}$ Stary BartıOMieJ, $W$ odwiedziny do polskich robotników rolnych, „Nasze Życie” 1938, nr 196, s. 14.
} 
do redakcji swoje teksty. Emigranci dzielili się własnymi przemyśleniami i nurtującymi ich problemami ${ }^{68}$. Zdarzało się, że niektórzy robotnicy nawet nadsyłali do redakcji własne wiersze. Należy wymienić wśród nich Mikołaja Sciepulonka, który zadebiutował wierszem „Na obczyźnie”. W poetyckiej formie robotnik zachęcał swoich kolegów i swoje koleżanki do czytania i prenumeraty tygodnika ${ }^{69}$.

Mimo tych sukcesów większość emigrantów sezonowych nie była zainteresowana czytaniem prasy. Za granicę wyjechali „za chlebem” i ciężko pracowali, by jak najwięcej zarobić na utrzymanie siebie i swoich rodzin. Wielu robotników pochodzących z Wileńszczyzny i Nowogródczyzny nie posiadało wykrystalizowanego poczucia świadomości narodowej i było biernych społecznie. Ludzie ci nie angażowali się w działalność społeczną w kraju, a więc tym bardziej nie zamierzali tego czynić za granicą. Tygodnik "Nasze Życie” prenumerowało zaledwie 2-3\% robotników, podczas gdy większość nie przejawiała nim żadnego zainteresowania. Miał na to wpływ m.in. znaczny odsetek analfabetów i półanalfabetów wśród emigrantów ${ }^{70}$.

Podsumowując można podkreślić, że Polska międzywojenna była dla gospodarki łotewskiej głównym eksporterem robotników sezonowych. Codzienne zachowania emigrantów kształtowały wyobrażenia Łotyszów na temat Polski i Polaków. Emigranci byli oceniani przez pryzmat tego, jak wykonywali swe obowiązki i spędzali czas wolny. Pod względem moralno-etycznym oraz zdolności do przystosowania się do miejscowych warunków życia i pracy robotnicy polscy byli zróżnicowani. Zdarzało się, że ci, którzy nie potrafili odnaleźć się w obcym kraju, szybko wracali do Polski. Niemniej większość robotników sumiennie wykonywała swoje obowiązki, dzięki czemu zaskarbiła przychylność pracodawców łotewskich.

\footnotetext{
${ }^{68}$ Polski robotnik rolny z Nowogródzkiego, Nie należy robić „ważnych rzeczy z głupstw”, „Nasze Życie” 1939, nr 221, s. 14.

${ }^{69}$ Listy... Listy, „Nasze Życie” 1937, nr 110, s. 18; Wasze wiersze, „Nasze Życie” 1938 , nr 166, s. 14.

${ }^{70}$ J. GRZYBOwSKI, Problematyka polskich emigrantów sezonowych na Łotwie na łamach tygodnika „Nasze Życie” w latach 1936-1939, „Studia Interkulturowe Europy Środkowo-Wschodniej" 13 (2020), s. 276-277.
} 


\section{BIBLIOGRAFIA}

\section{Archiwalia}

Archiwum Akt Nowych [AAN]

Zespół 15 - Ministerstwo Opieki Społecznej

Zespół 322 - Ministerstwo Spraw Zagranicznych

Dziarżaŭny archiŭ Hrodzienskaj voblasci [DAHV]

Zespół 551 - Urząd Wojewódzki w Nowogródku

Latvijas Valsts vēstures arhīvs [LVVA]

Zespół 3219 - Konsulat RP w Rydze

Lietuvos Centrinis Valstybès Archyvas [LCVA]

Zespół 51 - Urząd Wojewódzki w Wilnie

Zespół 148 - Wileńska Izba Rolnicza

\section{Opracowania}

ALBIN J., Polski ruch narodowy na Łotwie w latach 1919-1940, Wrocław: Wydawnictwo Uniwersytetu Wrocławskiego 1994.

GrZYBOwSKi J., Problematyka polskich emigrantów sezonowych na Łotwie na łamach tygodnika „Nasze Życie” w latach 1936-1939, „Studia Interkulturowe Europy Środkowo-Wschodniej” 2020, t. 13, s. 246-277.

JANOWSKA H., Emigracja zarobkowa z Polski 1918-1939, Warszawa: PWN 1981.

KoŁodziEj E., Wychodźstwo zarobkowe z Polski 1918-1939. Studia nad polityką emigracyjną II Rzeczypospolitej, Warszawa: Książka i Wiedza 1982.

Komunikat Konsulatu RP w Rydze, „Nasze Życie” 1939, nr 216, s. 14.

Komunikat Konsulatu RP w Rydze. Do sumienia i poczucia obywatelskiego robotnika, „Nasze Życie" 1938, nr 191, s. 13-14.

Komunikat Konsulatu RP w Rydze, „Nasze Życie” 1938, nr 167, s. 14.

Komunikat Konsulatu RP w Rydze, „Nasze Życie” 1938, nr 183, s. 13.

Konsul RP w Daugawpilsie T. Buynowski odwiedza robotników, „Nasze Życie” 1936, nr 82, s. 14.

Konsul RP w Rydze St. Ryniewicz wśród robotników, „Nasze Życie” 1938, nr 189, s. 13.

Kopeć B., W sprawie emigracji sezonowej do Łotwy, „Tygodnik Rolniczy” 1939, nr 1-2, s. 4-5.

KoPeĆ B., Wychodźstwo sezonowe z Ziemi Wileńskiej do Łotwy, Wilno 1938.

LANDAU L., Wychodźstwo sezonowe na Łotwę i do Niemiec w 1937 roku: na podstawie ankiety Instytutu Gospodarstwa, Warszawa: Książka i Wiedza 1966.

Lipiec - miesiącem propagandy „Naszego Życia”, „Nasze Życie” 1938, nr 188, s. 13.

List otwarty konsula RP w Rydze Stefana Ryniewicza, „Nasze Życie” 1936, nr 83, s. 14.

Listy... Listy, „Nasze Życie” 1937, nr 110, s. 18.

ŁossOwSKI P., Łotwa nasz sąsiad: stosunki polsko-łotewskie w latach 1918-1939, Warszawa: Mozaika 1990. 
Nabożeństwa katolickie dla robotników rolnych, „Nasze Życie” 1939, nr 216, s. 14.

Nagrody dla tych, którzy propagują „Nasze Życie”, „Nasze Życie” 1938, nr 191, s. 14.

Nasze porady i odpowiedzi, „Nasze Życie” 1938, nr 176, s. 14.

Nasze porady i odpowiedzi, „Nasze Życie” 1939, nr 222, s. 14.

O przedwczesnych powrotach i wysyłaniu pieniędzy w listach, „Nasze Życie” 1938, nr 198, s. 13.

Opieka duszpasterska nad emigracją polską, „Biuletyn Urzędu Emigracyjnego w Sprawach Migracji i Osadnictwa" 1929, nr 17, s. 141.

PALAŠA I., Darbaspēka imparts Latvijas laukos starpkraru perioda, Magistra darbs, Rīga 2005.

Płace robotników rolnych w Kurlandii, „Biuletyn Urzędu Emigracyjnego w Sprawach Migracji i Osadnictwa” 1930, nr 15, s. 176.

Polski robotnik rolny z Nowogródzkiego, Nie należy robić „,ważnych rzeczy z głupstw”, „Nasze Życie" 1939, nr 221, s. 14.

Rozpowszechniajcie „Nasze Życie”, „Nasze Życie” 1936, nr 74, s. 14.

SkóRA W., Życie codzienne polskich robotników rolnych na Pomorzu Zachodnim w dwudziestoleciu międzywojennym, [w:] Życie dawnych Pomorzan, cz. 1, red. W. Łysiak, Bytów-Poznań: Muzeum Zachodnio-Kaszubskie w Bytowie 2001, s. 189-207.

SKRZYPEK A., Stosunki polsko-łotewskie 1918-1939, Gdańsk: Marpress 1997.

STANKIEwICZ Z., Życie społeczno-religijne Polaków na Łotwie w okresie międzywojennym (1920-1940), [w:] Polacy na Łotwie, red. E. Walewander, Lublin: Redakcja Wydawnictw KUL 1993, s. $173-201$.

Stary BARTŁOMIEJ, Echa wypadków w Walmiera, „Nasze Życie” 1938, nr 192, s. 14.

Stary BARTŁOMIEJ, Po raz ostatni, „Nasze Życie” 1939, nr 217, s. 15.

STARY BARTŁOMIEJ, W odwiedziny do polskich robotników rolnych, „Nasze Życie” 1938, nr 196, s. 14.

STRANGA A., Kārḷa Ulmaṇa autoritatīvā režīma saimnieciskā politika 1934-1940, Rīga: Latvijas universitāte 2017.

Tu Konsulat RP w Rydze, „Nasze Życie” 1938, nr 173, s. 14.

Tu Konsulat RP w Rydze, „Nasze Życie” 1938, nr 178, s. 14.

Układ w sprawie emigracji robotników sezonowych na Łotwę, „Biuletyn Urzędu Emigracyjnego w Sprawach Migracji i Osadnictwa" 1928, nr 8, s. 4.

Uprzedzamy: bądźcie ostrożni, „Nasze Życie” 1936, nr 103, s. 18.

VIII-my komunikat Konsulatu RP w Rydze, „Nasze Życie” 1937, nr 142, s. 18.

Wasze wiersze, „Nasze Życie” 1938, nr 166, s. 14.

We własnym interesie, „Nasze Życie” 1936, nr 70, s. 14.

Wyjaśnienie w sprawie kontraktów, „Nasze Życie” 1938, nr 172, s. 13.

Zmiany w kontraktach na rok 1936, „Nasze Życie” 1936, nr 64, s. 19. 


\title{
ŻYCIE CODZIENNE POLSKICH ROBOTNIKÓW ROLNYCH NA ŁOTWIE W LATACH 1928-1939
}

\author{
Streszczenie
}

Polska międzywojenna była dla gospodarki łotewskiej głównym eksporterem robotników sezonowych. W latach 1928-1939 w rolnictwie łotewskim znalazło zatrudnienie ponad 100 tys. Polaków. Większość robotników rekrutowała się spośród małorolnych i bezrolnych chłopów, którzy przyjechali do Łotwy „za chlebem”. Polscy emigranci rolni byli dla Łotyszów swoistą wizytówką Polski. Ich codzienne zachowania kształtowały wyobrażenia Łotyszów na temat Polski i Polaków. Emigranci byli oceniani przez pryzmat tego, jak wykonywali swoje obowiązki i spędzali czas wolny. Pod względem moralno-etycznym robotnicy polscy byli zróżnicowani. Zdarzali się ci, którzy nie potrafili zaakceptować lokalnych zwyczajów życia i pracy, na skutek czego musieli szybko wrócić do kraju. Niemniej większość sumiennie wykonywała swe obowiązki i godnie prezentowała swój kraj, dzięki czemu zaskarbiła przychylność pracodawców łotewskich.

Słowa kluczowe: Polska; Łotwa; emigracja sezonowa; życie codzienne

\section{EVERYDAY LIFE OF POLISH AGRICULTURAL WORKERS IN LATVIA \\ IN THE YEARS 1928-1939}

\section{Summary}

Interwar Poland was the main exporter of seasonal workers for the Latvian economy. In the years 1928-1939 over 100,000 Poles found employment in Latvian agriculture. Most of the workers were recruited from small farmers and landless peasants who came to Latvia to buy bread. Polish agricultural emigrants were a specific showcase of Poland for Latvians. Their everyday behavior shaped Latvians' perceptions of Poland and Poles. The emigrants were judged on how they performed their duties and spent their free time. In terms of morality and ethics, Polish workers were diverse. There were those who could not accept the local customs of living and working, and as a result had to return quickly to the country. Nevertheless, most of them diligently performed their duties and presented their country with dignity, thanks to which they won the favor of Latvian employers.

Keywords: Poland; Latvia; seasonal emigration; everyday life 